\title{
Avoiding academic injustice in Saxony
}

Post-war Germany's enviable reputation as a law-abiding state is threatened by the harsh treatment of a handful of academics in the eastern Länder who once belonged to the Communist Party of the German Democratic Republic.

DR Armin Ermisch is still excluded from his post as head of the Department of Cell Biology at the University of Leipzig more than a year after he was first dismissed from it and in spite of his successful appeal to a German court. He was dismissed a second time in June this year. His appeal against that administrative decision will be held late in November. His post is no longer vacant, but occupied by a successor appointed before the first appeal had been adjudicated. It is a distressing tale and a haunting one, with all the makings of a serious injustice. It is also a cruel reminder of the damage that can follow from even beneficent events, in this case the reunification of Germany at the end of 1991.

Ermisch is a distinguished scientist, both in the old German Democratic Republic (GDR) and internationally. Like all academics at the University of Leipzig, his terms of employment are determined by the new Land of Saxony. As part of the reunification contract, Saxony and the other eastern Länder set up commissions to rule on the "personal integrity" of public employees, academics included (see Nature 359, 762; 1992). The first time round, Ermisch was one of many academics who were sent dismissal notices. His listed various discreditable behaviours, included complicity with the notorious secret police known as the Stasi, in particular informing on his academic colleagues, and the abuse of his position as head of a university department. Ermisch's appeal court exonerated him on all these counts and recommended reinstatement.

The second dismissal notice, delivered in June, cites two other grounds: membership of the Communist Party and (in that role) the provision of advice to students (at the end of 1990) that they should not take part in the street demonstrations that first suggested that even the apparently implacable GDR was not immune to change. Ermisch's fresh appeal consists of two parts: the argument that the advice he gave his students is a measure of his concern for their safety, and that his membership of the Party was an indispensable, but otherwise meaningless, qualification for the head of a university department.

The Ermisch case is not, of course, the only one to have arisen since reunification. A year ago, hundreds of appeals by academics against dismissal were in the eastern Länder courts. Not all of them were resolved in favour of the appellants, many of whom (and others, who had not appealed) found it easier (and possible) to find jobs elsewhere and move. Ermisch, well-known as he is, could probably do the same, although (in his fifties) probably only with some difficulty and disadvantage. But he appears to want to stay where he is, where over the years he has trained many able graduate students.

If the Ermisch case was an isolated illustration of how, during great social upheavals such as that of reunification, some degree of rough justice is unavoidable, it could be overlooked. But it is not. And the underlying issues of principle have not been faced as squarely as Germany's reputation would lead outsiders to expect. At this stage, of course, nobody pretends that the GDR was a democratic state or that the Communist Party was not both its chief means of coercion and the chief beneficiary of that state of affairs. But it is an assault on reality to suppose that all those who belonged to the old Party were equally responsible for its malign influence. That would be to suppose that the Party was not also coercive of its own members and to deny the simple truth of experience that membership became a duty for those holding certain public offices just as it was originally a privilege for others. Saxony seems to have put aside both these arguments.

Several questions then arise. It is (or it should be) readily appreciated that people whose lives have been perverted for a generation should be bitterly resentful of the instruments of their past torment, but will not insensitive retribution engender further bitterness? It is especially dangerous when academic institutions witness acts of injustice such as that at Leipzig, for universities have a special duty of tolerance. And, given the likelihood that an appeal by Ermisch to the federal Constitutional Court at Karlsruhe would almost certainly succeed, should not Saxony give in now, before causing further embarrassment for itself?

\section{Travel loosens tongues}

Britain's prime minister has acknowledged in Japan what he would not in Britain - that British science has been mishandled.

TRAVEL does not always broaden the mind (it can also be a reinforcement of prejudice), but the visit of the British prime minister, Mr John Major, to Japan last week appears to have had one beneficial effect. Major is the inheritor of a government which, over nearly 15 years, has dealt insensitively, even foolishly, with British science, substituting for what may previously have been unfounded optimism a general demoralization. The British research community now waits 